\title{
Naar een diachrone blik op de verdiensten van Nederlandstalige auteurs
}

\author{
Remco Sleiderink, Helleke van den Braber, Nina Geerdink, Laurens Ham ${ }^{1}$
}

\author{
NEDLET 25 (1): 7-26 \\ DOI: 10.5117/NEDLET2020.1.002.SLEI
}

\begin{abstract}
This article argues that it is both important and viable to develop a diachronic perspective on the profits of literary authors in the Low Countries. Up to now, conceptual and theoretical boundaries between different subdisciplines within Dutch literary studies have resulted in a compartmentalized, fragmentary narrative of the economic, social and symbolic profits of literary authors throughout the centuries. On the basis of a survey of the theoretical frameworks dominant in the subdisciplines of medieval, early modern and modern Dutch literature, we highlight the opportunities and difficulties for a diachronic perspective on financial advancement, focusing both on practice and discourse. In addition, we propose a schematic model that tries to overcome the difficulties and enables us to profit from the opportunities. This proposal allows for a sharper focus on both the practice of and discourse on literary authors' economic gain from a diachronic perspective.
\end{abstract}

Keywords: authorship; profits; diachronic perspective; cultural sociology; cultural history; study of poetics

Dat volgens de meest recente literatuurgeschiedenis van de Nederlandstalige literatuur de professionele auteur meermaals 'voor het eerst' ontstaat, hoeft geen verbazing te wekken, hoe merkwaardig dat ook klinkt. De praktijk van de literatuurgeschiedschrijving is sinds de tweede helft van de twintigste eeuw verkokerd geraakt: periodespecialisten schrijven ieder over hun eigen periode en zijn nauwelijks met elkaar in gesprek. Disciplinaire samenwerking is eerder synchroon dan diachroon van karakter en projecten die wél 
periode-overschrijdend zijn, resulteren vaak in publicaties die, net als de in 2017 voltooide Geschiedenis van de Nederlandse literatuur (GNL), bestaan uit verschillende delen (boekdelen, hoofdstukken, paragrafen) waarin specialisten zich met casussen uit hun eigen periode bezighouden. Het is aan de lezer van deze publicaties als geheel - als die er al zijn - om op zoek te gaan naar lijnen, verschillen, overeenkomsten. ${ }^{2}$ Vanuit de literair-historische behoefte aan verklarende narratieven creëert elke periode binnen deze verkokerde literatuurgeschiedschrijving zijn eigen begin- en eindpunt, met daarbinnen liefst enkele 'revoluties'. Dit is een internationaal fenomeen. ${ }^{3}$

Binnen de literatuurgeschiedschrijving lijkt de laatste decennia echter weer meer aandacht te komen voor een diachroon perspectief. In onderwijscurricula is er vaker ruimte voor periodeoverstijgende cursussen ${ }^{4}$ en in het onderzoek is de laatste decennia regelmatig opgeroepen tot een diachrone literatuurgeschiedschrijving. Ook zijn er daadwerkelijk pogingen gedaan langere periodes collectief te bestuderen zonder de breukmomenten van de dominante periodisering leidend te laten zijn. ${ }^{5}$ Met betrekking tot de geschiedenis van het auteurschap beogen dergelijke studies veelal de traditionele scheidslijn tussen auteurschap dat afhankelijk was van patronage (tot in de zeventiende eeuw) en auteurschap dat zich verhield tot de onafhankelijke literaire markt (vanaf de achttiende eeuw) te doorbreken en te laten zien dat het moderne auteurschap wortelt in eerdere periodes. ${ }^{6}$ Omdat tot voor kort het idee was dat literair patronage in de vroegmoderne Republiek nauwelijks een rol speelde, ${ }^{7}$ heeft dit narratief binnen de Nederlandse letterkunde een marginale rol gespeeld. Ook de doorbreking ervan heeft dus weinig aandacht gehad.

Op basis van onze analyse van de narratieven rond auteurschap in de $G N L$ in een eerdere publicatie, denken wij dat er nog andere, belangrijkere, redenen zijn voor het ontbreken van een diachroon perspectief op verdiensten binnen de Nederlandse letterkunde: enerzijds het ontbreken van aandacht voor de auteursverdiensten in het algemeen, anderzijds de theoretische verkokering van de subdisciplines binnen de letterkundige neerlandistiek: voor elke periode zijn andere methoden en theorieën ontwikkeld, om aan het eigene van de periode recht te doen. ${ }^{8}$ Om het probleem van die theoretische verkokering te ondervangen, vertrekken we in dit artikel vanuit een beschrijving van de status quo: welke theorievorming is met het oog op auteurschap relevant in de letterkunde en specifiek binnen de subdisciplines van de Middelnederlandse, vroegmoderne en moderne letterkunde? Vervolgens onderzoeken we waar de verschillende theoretische kaders elkaar kunnen ontmoeten voor vruchtbaar diachroon onderzoek. We doen dat aan de hand van een schema dat als 'blikopener' dient en 
waarvan we in het laatste deel van dit artikel de mogelijkheden en beperkingen zullen toelichten en illustreren.

\section{Theoretische achtergronden: waar we vandaan komen}

Een diachroon perspectief op de verdiensten van auteurs in de literatuurgeschiedenis van de Nederlandse letterkunde mag dan ontbreken, naar de economie van het symbolisch kapitaal van auteurs is de afgelopen decennia wél veel (vroeg)modern-letterkundig onderzoek gedaan. Dat de poging economisch kapitaal te verwerven zo veel minder goed is onderzocht dan de zoektocht naar symbolisch kapitaal (aanzien, prestige, of ook wel: waarde), ${ }^{9}$ heeft te maken met de manier waarop het werk van Bourdieu een rol gespeeld heeft in het onderzoek naar de Nederlandse letterkunde.

Hoewel we ons bij ons gebruik van Bourdieus termen en concepten terdege rekenschap geven van de genuanceerde (maar ook niet altijd even consequente) manier waarop hij ze zelf heeft uitgelegd en toegepast, willen we zijn terminologie in dit themanummer vooral pragmatisch inzetten. Het is niet onze bedoeling een bijdrage te leveren aan de discussie over de precieze inhoud en betekenis van zijn veldtheorie. Wel willen we laten zien dat zijn centrale tegenstelling economisch-symbolisch onmisbaar is in elke discussie over auteurschap en verdiensten.

Volgens Bourdieu circuleren in het culturele veld vier kapitaalsoorten: economisch kapitaal (een kapitaalsoort die direct omzetbaar is in geld, en waar bijvoorbeeld ook copyright onder valt), cultureel kapitaal (voor schrijvers belichaamd door en ingezet via hun schrijverschap), sociaal kapitaal (het netwerk van connecties dat door schrijvers kan worden gemobiliseerd) en symbolisch kapitaal. ${ }^{10}$ Symbolisch kapitaal valt die schrijvers toe die erin slagen hun culturele en sociale kapitaal om te zetten in aanzien of prestige. ${ }^{11}$ Dat lukt ze via de erkenning die ze van anderen krijgen - van critici, uitgevers, redacteuren, collega-schrijvers of lezers. Bezit van economisch kapitaal is voor die omzetting in symbolisch kapitaal geen voorwaarde, integendeel. ${ }^{12}$ Als schrijvers uit zijn op de accumulatie van symbolisch profijt, dan zullen ze hun zoektocht naar economisch profijt moeten verhullen of ontkennen. ${ }^{13}$

Bourdieu geeft zelf drie redenen waarom het in het literaire discours (en daarmee ook in het onderzoek naar dat discours) voortdurend over symbolisch kapitaal gaat, en zo zelden over economisch kapitaal. In de eerste plaats heeft dat met de structuur van het literaire veld te maken: verlangen naar bezit van symbolisch kapitaal wordt in het (naar 
autonomie neigende) veld als legitiem gezien, terwijl dat bij verlangen naar economisch kapitaal veel minder het geval is. Bourdieu presenteert deze tegenstelling als relatief overzichtelijk: hij gaat ervan uit dat een al te openlijke zoektocht naar economische resultaten per definitie de literaire reputatie en daarmee de veldpositie van een auteur onder druk zet. In de tweede plaats hangt het met het gedrag van schrijvers samen. Auteurs, stelt Bourdieu, kunnen alleen met succes strijden om symbolisch kapitaal als ze hun zoektocht naar winst (of dat nu economische of symbolische 'winst' is) zorgvuldig framen als belangeloos. Alleen profijt dat verhuld wordt nagestreefd, dat wordt vermomd als niet-winstgericht, betaalt zich niet alleen economisch, maar ook symbolisch uit. ${ }^{14}$ In de symbolische economie, stelt Bourdieu, spinnen schrijvers er garen bij als ze hun economische belangen nergens expliciet maken of alleen eufemistisch ter sprake brengen. ${ }^{15}$ Dat betekent dat hun daadwerkelijke economische situatie zeer kan afwijken van de manier waarop ze die situatie presenteren. Maar in de derde plaats is dit niet alleen een slinkse framing van auteurs die heel goed weten dat er eigenlijk economisch profijt op het spel staat; volgens Bourdieu hebben auteurs er wezenlijk belang bij oprecht te geloven in de 'regels van het spel' dat ze spelen en legitimeren ze hun eigen werk en positie het beste door hun overtuiging dat hun arbeid vooral belangeloos is. Dit is wat hij de illusio noemt. ${ }^{16}$

In veel van Bourdieus analyses staan verhulling en symbolisch kapitaal dus centraal. Een onthulling, en met name een onthulling van het streven naar economisch kapitaal, zou voor veel auteurs in de visie van Bourdieu immers de doodsteek zijn voor het symbolisch kapitaal dat ze hebben opgebouwd, en daarmee voor hun standing en positie in het veld. ${ }^{17}$ Deze gedachtegang heeft goede voedingsbodem gevonden in de letterkundige neerlandistiek, met name als het gaat om moderne literatuur, en de al bestaande focus van het onderzoek op het (verhullende) literaire discours en de strijd om symbolisch kapitaal enkel versterkt. Bourdieus denken liet zich immers goed verenigen met een ander theoretisch model dat de Nederlandse letterkunde diepgaand beïnvloed heeft: het poëticamodel.

Dat schema werd in 1953 geïntroduceerd door M.H. Abrams, die betoogde dat de oriëntatie van auteurs verschoof van een gerichtheid op mimese naar een gerichtheid op expressie. Daarnaast onderscheidde hij nog een poëticale oriëntatie op de lezer - vooral in de oudere literatuur - en een poëticale oriëntatie die zich met name op het werk zelf richtte - vooral in de twintigste-eeuwse letterkunde. ${ }^{18}$ A.L. Sötemann vertaalde dit model in de jaren 1970 en 1980 naar het Nederlandse taalgebied, waarbij hij de indruk probeerde weg te nemen dat bepaalde poëtica's zouden 
domineren in bepaalde tijdvakken. ${ }^{19}$ Het poëticamodel zou zich er in zijn operationalisering vooral voor lenen om synchrone stromingen en bewegingen met elkaar te contrasteren. ${ }^{20}$ Belangrijk is dat een studie van de literaire wereld vanuit het poëticamodel zich louter op het niveau van opvattingen begeeft: op de economische basis 'onder' de literatuur richt Sötemanns model zich niet, en dat gold dus ook voor het vele poëticaal georiënteerde onderzoek dat sinds de jaren 1970 naar alle periodes van de Nederlandse letterkunde uitgevoerd werd. In de loop der tijd is de context waarbinnen literatuur geproduceerd werd steeds belangrijker geworden in het onderzoek. Dat proces verliep voor alle subdisciplines (de middeleeuwse, vroegmoderne en moderne letterkunde) anders en resulteerde niet altijd in diepgravend onderzoek naar de economische aspecten van het auteurschap.

In de moderne letterkunde kwam de studie naar poëtica's via het werk van onder meer Kees van Rees en Gillis Dorleijn samen met de Bourdieuaanse veldanalyse. Poëtica's - ook wel: literatuuropvattingen - functioneerden in het werk van Van Rees en Dorleijn breder, namelijk als instrumenten om de strijd en onderhandelingen bij allerlei spelers en instituties in het literaire veld te begrijpen. ${ }^{21}$ In de synthetiserende bundel De productie van literatuur (2006) staan handzame schema's die het literaire veld in verschillende periodes weergeven. Daarin zijn voor de recentste periode ook spelers opgenomen als de Vereniging van Letterkundigen (tegenwoordig: Auteursbond) en het Fonds voor de Letteren (tegenwoordig: Nederlands Letterenfonds), die de economische belangen van auteurs (mede)behartigen. ${ }^{22}$ In de artikelen in deze bundel zijn echter geen hoofdstukken over die twee instituties of over de ministeries voor cultuur opgenomen, waardoor belangrijke economische aspecten van de literaire wereld buiten beeld blijven. In een recentere bundel over de geschiedenis van literaire instituties in Nederland en Vlaanderen, Van hof tot overheid, krijgt de sociaal-economische kant wel iets meer aandacht, vooral in de hoofdstukken over hof en klooster in de middeleeuwen en in het slothoofdstuk waarin de rol van de overheid in de moderne periode centraal staat. ${ }^{23}$

Onder invloed van de internationale cultural turn namen minder tekstgecentreerde en meer contextgebonden, cultuurhistorische benaderingen vanaf het eind van de jaren 70 een hoge vlucht in de historische letterkunde. Dit leidde in de vroegmoderne letterkunde tot toenemende aandacht voor tal van genres die niet tot de hogere literatuur gerekend werden en daardoor lang buiten de canon waren gevallen. Het gelegenheidskarakter van de vroegmoderne literatuur kreeg een centrale plek in het onderzoek, met aandacht voor sociale, religieuze, politieke en 
wetenschappelijke imperatieven voor en gevolgen van literaire teksten, maar niet voor economische. ${ }^{24}$ Materieel profijt was immers geen thema dat in de literatuur zelf aangekaart werd. De tegelijkertijd langzaam toenemende aandacht voor auteurs en hun zelfrepresentatie leidde, om andere redenen, ook niet tot onderzoek naar economische aspecten van dat auteurschap. Die redenen zijn de invloedrijke concepten van selffashioning en, in mindere mate, career criticism. Stephen Greenblatts onderzoek naar self-fashioning stelt centraal hoe auteursidentiteiten gecreëerd worden tussen persoon en werk enerzijds en de politieke en religieuze machten van de tijd anderzijds, en gaat daarmee in eerste instantie voorbij aan economische aspecten. ${ }^{25}$ Het career critisicm van Cheney en d'Armas beoogt literaire carrières te onderzoeken, maar beschouwt die enkel vanuit intellectuele ambities die nadrukkelijk losgekoppeld worden van eventuele andere motieven of carrières van een auteur. ${ }^{26}$ Het career criticism is dus, in de terminologie van Bourdieu, volledig gericht op het verwerven van symbolisch kapitaal. ${ }^{27}$ Bij self-fashioning en career criticism én het daardoor beïnvloede neerlandistische onderzoek naar zelfpresentatie zijn (literaire) teksten de voornaamste bronnen voor het onderzoek, terwijl deze voor wat betreft economische aspecten over het algemeen sterk verhullend zijn. Expliciete aandacht voor verdiensten is er de afgelopen decennia, als gevolg van toenemende samenwerking tussen boekhistorici en letterkundigen, eigenlijk voornamelijk geweest in de context van onderzoek naar het boekbedrijf in met name de tweede helft van de achttiende eeuw. ${ }^{28}$

In de Middelnederlandse letterkunde hebben auteursverdiensten juist wel volop in de belangstelling gestaan. Vanuit een toenemende aandacht voor de receptie van literaire werken (receptie-esthetica) kwam de focus te liggen bij het beoogde publiek en dan met name bij de machthebbers die optraden als literair mecenas. Frits van Oostrom, die in 1981 deze aanpak als eerste bepleitte in navolging van het onderzoek in de Altgermanistik, vergeleek de positie van een middeleeuwse auteur zelfs met die van een moderne autocoureur. De afhankelijkheid van de geldschieter zou dermate groot zijn, dat de sponsor de literatuur volledig kon bepalen: 'wiens brood men eet, diens woord men spreekt'. ${ }^{29}$ Dergelijk onderzoek naar hof en mecenaat werd echter al snel genuanceerd, ook door Van Oostrom zelf. Enerzijds bleek dat vorm en inhoud niet eenzijdig werden bepaald door de opdrachtgevers, maar het resultaat waren van een creatieve dynamiek tussen auteur en publiek. ${ }^{30}$ Anderzijds bleek dat literatuur ook zonder inmenging van het hof kon ontstaan. 


\section{Theoretische uitgangspunten: de operationalisering van diachroon onderzoek}

De schets van de theoretische achtergronden die de onderzoeksagenda voor wat betreft auteurschap in de afgelopen decennia bepaald hebben, laat zien dat de drie subdisciplines van de letterkundige neerlandistiek anders met auteursverdiensten zijn omgegaan. Er zijn grote verschillen in de mate waarin zij de factor 'materieel profijt' in ogenschouw hebben genomen voor de eigen periode, maar bovendien loopt de 'taal' die gesproken wordt bij het onderzoeken van auteurschap erg uiteen: dat blijkt alleen al als je vergelijkt wat door specialisten van de drie periodes onder 'literatuur' verstaan wordt. Toen we voor het eerst om tafel zaten met een groep letterkundigen gespecialiseerd in periodes van de middeleeuwen tot heden, werd meteen duidelijk dat verschillen in terminologie en opvattingen over theoretische achtergronden ons parten zouden spelen in het gezamenlijk beantwoorden van vragen over auteurschap en verdiensten.

Het centrale spanningsveld, zo bleek in onze besprekingen en zo blijkt ook uit het historiografisch overzicht in de vorige paragraaf, is dat tussen onthullend en verhullend gedrag. Zo zien we van de middeleeuwen tot heden schrijvers die openlijk uitkwamen voor hun (gebrek aan) economisch succes tegenover schrijvers die hun werk het liefst zo min mogelijk met geldkwesties associeerden - of ze zich nu ondernemend opstelden of daar wars van waren, freelanceklussen aanpakten of het bij hun autonome werk hielden, zich lieten steunen door weldoeners of zich niet met hen inlieten. We waren het bij alle verschillen dus eens dat er in alle periodes een duidelijk onderscheid is tussen openlijk ondernemende auteurs en auteurs die dat minder, niet, of alleen verhuld waren. Auteurs hebben de neiging buiten de spotlights, dus tegenover insiders als collega-schrijvers, uitgevers en redacteuren, een heel ander beeld te geven van hun economische verlangens en keuzes, dan het beeld dat ze en public uitdragen, tegenover hun lezers of toehoorders.

Het is vervolgens een relevante vraag of het spel dat auteurs speelden rond onthullen en verhullen van (verlangen naar) profijt in elk van de periodes evenzeer noodzakelijk is geweest, met name voor die schrijvers die de ambitie hadden artistiek voor vol te worden aangezien. Spannender nog wordt het als we de blik richten op al die literaire auteurs die er om allerlei redenen door de eeuwen heen voor kozen om zichzelf min of meer onverhuld als cultureel ondernemer op te stellen. De vraag is welk belang zij van periode tot periode hadden bij het onthullen van hun ondernemerschap. 
Hun gedrag en zelfrepresentatie als schrijver-ondernemer zijn tot nu toe grotendeels onderbelicht gebleven.

Naast de binaire oppositie verhuld-onthuld, speelt in al deze gevallen ook de hierboven toegelichte oppositie economisch-symbolisch een rol. Ons uitgangspunt is dat in elke periode van de literatuurgeschiedenis auteurs actief waren die deze opposities ondermijnden of op scherp stelden, bijvoorbeeld door een anti-commercieel discours te combineren met inventief ondernemerschap, door een lucratieve deal met een uitgever te presenteren als een puur idealistische samenwerking, of door een mecenas en public hoger te waarderen voor diens begrip en inzicht dan voor diens harde cash.

Voor onze gezamenlijke theoretische uitgangspunten betekent dit dat we altijd óók de beeldvorming over economische verdiensten mee willen wegen: hoe wordt over (het verlangen naar) verdiensten geschreven en gesproken door de auteurs zelf en hun omgeving, en hoe is dit discours afhankelijk van het publiek dat daarmee aangesproken wordt? Wanneer dit niet, of niet op dezelfde manier of in dezelfde mate meegenomen wordt, is vergelijken door de tijd heen heel lastig. We ontwierpen een schema dat zich ervoor leent het discours en gedrag van auteurs diachroon vergelijkend in kaart te brengen, op basis van hun houding tegenover en omgang met ondernemerschap, verdienmogelijkheden en geld. ${ }^{31}$ Het schema is nadrukkelijk bedoeld als blikopener. Het helpt ons om het profijtgerichte gedrag van auteurs over de periodes heen te kunnen vergelijken, en in te zien op welke punten zo'n vergelijking zin heeft. Ook biedt deze blikopener inzicht in de manier waarop deze vergelijking gestuurd wordt door de contextuele en, meer specifiek, institutionele inbedding van auteurschap in verschillende periodes. Het schema is zo een vertrekpunt voor het door de tijd heen onderzoeken van de interactie tussen de zoektocht naar de verschillende kapitaalsoorten en de kwestie van openlijkheid dan wel noodzakelijke verhulling. Het biedt daarmee meer inzicht in de sociale en economische voorwaarden voor auteurschap door de eeuwen heen en in de spanningen die daarin speelden.

Ons schema neemt het beschikbare bronmateriaal als uitgangspunt. Voor onderzoek naar verdiensten heb je uitingen nodig, of dat nu een factuur is met een bedrag voor verleende literaire diensten of een interview waarin een auteur zich negatief uitlaat over verdiensten, een contract tussen stadsdichter en stadsbestuur of een poëticaal gedicht waarin verdiensten benoemd worden. Juist omdat de aard en beschikbaarheid van bronmateriaal voor elke periode verschillend is, is het schema belangrijk als blikopener: het stelt ons in staat die verschillen waar te nemen, maar ook om daaraan voorbij te gaan zodat we parallellen kunnen ontdekken. 
In het schema kunnen verschillende ‘uitingen' van een auteur met betrekking tot economische verdiensten gesitueerd worden, ook ten opzichte van elkaar. We maken onderscheid tussen publieke (in theorie voor iedereen toegankelijke) en niet-publieke (voor een beperkt aantal mensen toegankelijke) uitingen, en vervolgens tussen discursieve en niet-discursieve uitingen. ${ }^{32}$ Een uiting kan bijvoorbeeld net zo goed een letterlijke uitspraak zijn ('ik hoop met dit literaire werk geen/veel geld te verdienen') als een handeling of gedrag, zoals het al dan niet aannemen van een geldbedrag van een mecenas of de keuze om al dan niet te publiceren in een tijdschrift met een bepaalde reputatie. Voor elke uiting kan in het schema aangegeven worden hoe die zich verhoudt tot het verdienen van geld met literair werk: positief, neutraal of negatief.

\section{De blikopener: uitingen over verdiensten in schema}

1. Publieke uiting

a. discursief ${ }^{33}$

i. Positief ('ik heb behoefte aan geld')

ii. Neutraal ('ik krijg geld / geen geld' of 'ik heb het hier niet over')

iii. Negatief ('ik heb geen behoefte aan geld')

b. niet-discursief (handeling)

i. Positief ('ik laat me fotograferen met een dure auto of schilderen met een hele dure mantel')

ii. Neutraal ('ik neem geld wel of niet aan, maar doe daar niet zo veel mee')

iii. Negatief ('ik poseer als een armoedzaaier of als iemand die niet om geld geeft / bohemien, dandy etc.')

2. Niet-publieke uiting

a. Discursief (bijv. briefwisseling, mondelinge contacten)

i. Positief ('ik heb behoefte aan geld')

ii. Neutraal ('ik krijg geld / geen geld')

iii. Negatief ('ik heb geen behoefte aan geld')

b. niet-discursief (handeling)

i. Positief (schrijver aanvaardt geld enthousiast of laat blijken er behoefte aan te hebben)

ii. Neutraal (schrijver ontvangt geld)

iii. Negatief (schrijver aanvaardt geld niet dat wel aangeboden wordt) 


\section{De blikopener: mogelijkheden}

Het schema is ontworpen om spanningen op het spoor te komen en dat kan op verschillende niveaus. Spanningen tussen de uitingen van een en dezelfde auteur, zoals in het door ons centraal gestelde spanningsveld tussen onthullend en verhullend gedrag, zijn het makkelijkst op te sporen. Het schema helpt daarnaast ook om tegengestelde uitingen van verschillende auteurs binnen een tijdvak zichtbaar te maken, en het toont chronologische ontwikkelingen: spanningen tussen het ene (vroege) moment en het andere (latere) moment in de carrière van een auteur, of tussen momenten in de carrières van meerdere auteurs. Bovendien kunnen op al die niveaus ook uitingen van anderen dan de auteur zelf meegenomen worden.

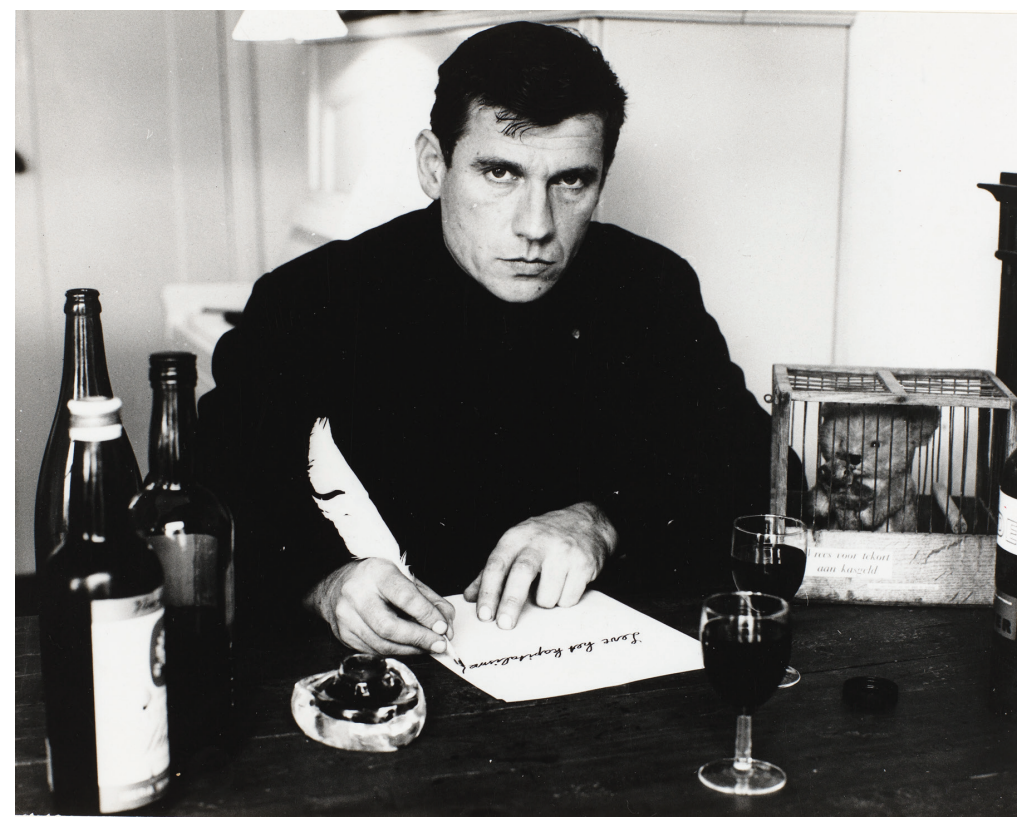

Afbeelding 1 Portret van Gerard Reve tijdens het schrijven met een ganzeveren pen. Fotoportret door Steye Raviez, 1968.

Collectie Rijksmuseum Amsterdam, objectnummer RP-F-2011-21-31-8

Gerard Reve, bijvoorbeeld, liet zich diverse keren fotograferen met een glas wijn voor zich, schrijvend met een ganzenveer, omringd door objecten met heel diverse culturele en religieuze achtergronden. Hij verbond zich daarmee op een heel nadrukkelijke manier met de parafernalia van de romantische bohemien-schrijver (1.b.iii). Op een van die foto's (zie afbeelding 1), 
een werk uit 1968 van Steye Raviez, staan er zelfs niet minder dan vier flessen wijn op zijn bureau, deels vol en deels halfleeg, en twee gevulde glazen. Reve kijkt indringend in de lens met voor zich een blad waarop hij zojuist 'Leve het kapitalisme!' heeft geschreven (1.a.i). ${ }^{34}$ Dat past bij de uitgesproken en volkomen tegengestelde zelfrepresentatie die hij tezelfdertijd cultiveerde: die van de zakenman die 'een winkel' draaiende moest houden (1.a.i). Hoe zorgvuldig deze foto is geënsceneerd, blijkt wel wanneer we kijken naar het merkwaardige kooitje dat zich rechts in beeld bevindt. ${ }^{35}$ Daarin staat een knuffelbeertje met een kleiner knuffeltje in de armen. Dit object zou je poëticaal of levensbeschouwelijk kunnen interpreteren - een knuffelkonijn speelt bijvoorbeeld in Reves debuutroman De avonden (1947) een belangrijke rol, en je zou deze twee diertjes zelfs als een variant op Maria-met-kind kunnen beschouwen - maar ook kunnen betrekken in de verdienthematiek. Wordt met dit object uitgedrukt dat de schrijver zich door financiële beslommeringen gekooid voelt? Die interpretatie wordt versterkt door de krantenkop die op het kooitje is geplakt: 'Vrees voor tekort aan kasgeld'. Deze paradoxale en artistieke verbeelding van Reves visie op literair verdienen zou je vervolgens in verband kunnen brengen met zijn handelingen buiten de publiciteit: zo vroeg hij achter de schermen veel geld voor het publiceren van onbelangrijk werk (2.a.i). Omdat die uitingen naast elkaar staan, doet zich een spanning voor die we kunnen analyseren in termen van belangen (al dan niet verhuld) en kapitaal (economisch, symbolisch). ${ }^{36}$ Een bijkomende kwestie in het geval van Reve, die bij een analyse ook benoemd moet worden, is de mate waarin er ironie in het spel is: beide zelfrepresentaties, maar zéker die van bohemien-schrijver, lijken met veel spot naar voren te worden gebracht.

Waar we een auteur en zijn uitingen ook situeren: het blijft een schematische weergave. Zodra dankzij het schema de blik geopend is, moet altijd de vraag gesteld worden waarom sprake is van een bepaalde situering en welke gevolgen dat heeft voor de materiële én symbolische waardering voor een auteur. Hoe wordt gereageerd op deze stellingnames en handelingen en hoe heeft dat opnieuw zijn weerslag op gedrag en woorden van de auteur? Ook het ontbreken van bepaalde uitingen - bijvoorbeeld nietpublieke, niet-discursieve uitingen - kan betekenisvol zijn: het kan iets zeggen over de auteur en de context waarin die opereert, maar het kan evenzeer te maken hebben met de beschikbaarheid of juist afwezigheid van relevante bronnen (zie daarover de volgende paragraaf).

In het voorbeeld van Reve zijn alle genoemde uitingen van de auteur zelf afkomstig: hij creëerde de spanning. Er kan echter ook een spanningsveld ontstaan tussen uitingen van een auteur zelf en de manier waarop er 
óver de auteur en diens werk geoordeeld wordt. Een auteur kan bijvoorbeeld erg hameren op symbolisch profijt (1.a.iii of 1.b.iii) maar dat toch niet krijgen, bijvoorbeeld omdat het werk commercieel succesvol is (1.b.ii) en daarom tot de populaire literatuur wordt gerekend. Ook kunnen de uitingen van een auteur versterkt worden door anderen. Dat gebeurde bij Joost van den Vondel toen een groep 'liefhebbers' in 1644 zijn Verscheide gedichten uitgaf met op het frontispice (zie afbeelding 2) een allegorie van de poëzie met daaronder een geldbeluste putto die aangevallen wordt door de dichterszwaan en de putto die, met lauwerkrans, de eer verbeeldt, ${ }^{37}$ of bij Multatuli als hij door Braakensiek wordt afgebeeld als straatarme, op een houtje bijtende lijdende schrijver op een zolderkamertje (zie voor de afbeelding het volgende artikel in dit themanummer). Deze afbeeldingen van de categorie 1.b.iii zijn zeer sturend geweest voor de beeldvorming over de economische en symbolische situatie van auteurs als Vondel en Multatuli.

Dat de blikopener goed werkt als vertrekpunt voor diachroon onderzoek, blijkt wanneer deze gebruikt wordt voor een vergelijking van Vondel met Willem Kloos. Kloos profileerde zich in het culturele veld van zijn tijd in de Nieuwe gids, openlijk dus, als de dichter en schrijver die volledig recht had op elke symbolische erkenning die dat veld maar te bieden had. Die erkenning kwam hem toe, vond hij, op grond van zijn uitzonderlijke dichterschap. Het is belangrijk veldprestige in dit geval niet te verwarren met maatschappelijk aanzien: Kloos was openlijk uit op het eerste, maar juist niet op het laatste. Hij stak zijn behoefte aan symbolische erkenning niet onder stoelen of banken, maar leidde ondertussen een anti-burgerlijk bohemien-bestaan en toonde zich niet geïnteresseerd in banen, geld of maatschappelijke positie. Deze uitingen van Kloos zijn in het schema onder te brengen bij 1.a.iii en 1.b.iii. Ondertussen zijn er ook bronnen beschikbaar waaruit blijkt dat hij er achter de schermen van overtuigd was dat zijn ijzersterke symbolische positie hem ook het recht gaf op discrete financiële ondersteuning. In een (al te onthuld) freelancebestaan of literaire klussen was hij niet geïnteresseerd, hij was uit op de verhulde giften die collega-schrijvers en rijke liefhebbers hem konden en wilden geven. ${ }^{38}$ Uit zijn brieven blijkt dat hij dit soort hulp zag als een legitiem middel van bestaan, en als een soort gematerialiseerde vorm van de symbolische erkenning waar hij op uit was. De kring rond de Tachtigers moest hem in leven houden, zo blijkt uit zijn correspondentie, als tegenprestatie voor zijn uitzonderlijke werk. En inderdaad gebeurde dit ook. De uitingen die Kloos deed, kunnen hiermee worden ondergebracht in de categorieën 2.a.i. en 2.b.i. 


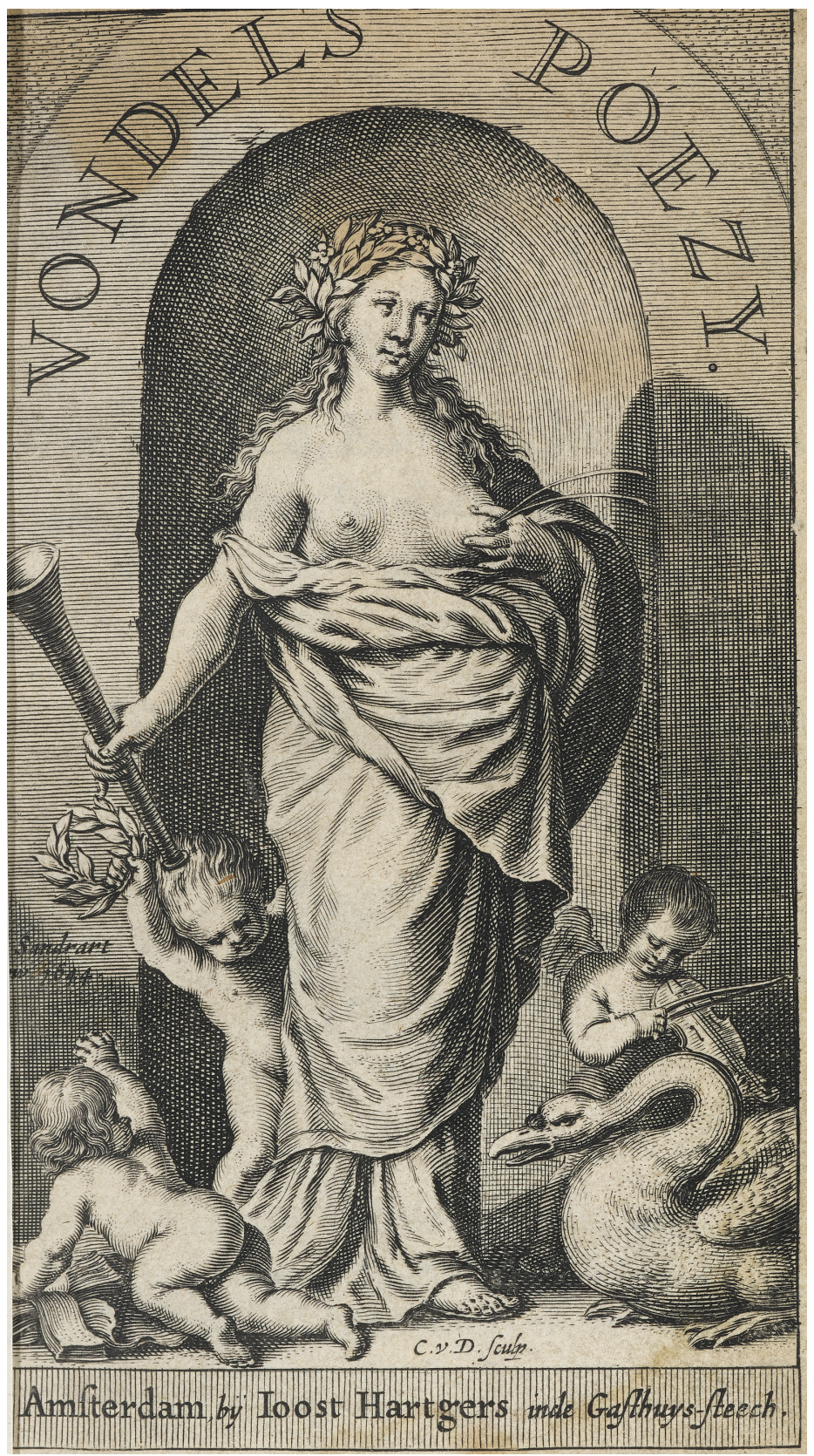

Afbeelding 2 Titelpagina J. van den Vondel, Verscheide gedichten. Amsterdam: J. Hartgers, 1644. Gravure door Corn. van Dalen naar J. von Sandrart.

Bijzondere collecties UBA, sign. OTM Vondel $2 \mathrm{H} 1$ 
Voor Vondel geldt ook dat hij openlijk symbolisch kapitaal nastreefde. Over economisch kapitaal liet hij zich publiekelijk nauwelijks uit. Af en toe werden de giften die hij verkreeg wel genoemd, maar altijd op neutrale wijze (1.a.ii). Net als Kloos had Vondel een sterke reputatie. Of hij vond dat die positie hem recht verleende op financiële ondersteuning, weten we niet; wel dat zijn biograaf Brandt van mening was dat hij daar recht op had. ${ }^{39}$ Hoe dat ook zij: Vondel werd regelmatig financieel ondersteund, net als in Kloos' geval met name door giften, al kwamen die bij Vondel in de eerste plaats van mecenassen, ${ }^{40}$ terwijl Kloos vooral profiteerde van ondersteuning door collega-schrijvers: 2.b.ii.

Hoewel de omgang van Kloos en Vondel met economische verdiensten op het eerste gezicht dus zeer vergelijkbaar was (in beide gevallen profiteerden ze verhuld van ondersteuning maar lieten ze zich daar publiekelijk neutraal of negatief over uit), laat de situering in het schema enkele verschillen zien. Van Kloos hebben we correspondentie waaruit blijkt dat hij in beperkte kring wel degelijk om geld vroeg (2.a.i.) en in beperkte kring liet blijken op die verdiensten uit te zijn (2.b.i), van Vondel weten we dit, bij gebrek aan bronnen, niet. Een tweede verschil, Vondels neutrale uitingen over zijn verdiensten (1.a.ii), die bij Kloos ontbreken, maakt duidelijk dat een casus ingebed moet worden in de context van de eigen tijd. Doordat we die samenhang tussen uitingen en context scherper gaan zien en beter kunnen vergelijken, krijgen we meer inzicht in de relatie tussen auteurschap en geld in diachroon perspectief.

Vondel zette zich minder expliciet dan Kloos af tegen economische verdiensten en was in zijn verhulling minder strikt dan Kloos, doordat hij zijn verdiensten publiekelijk niet volledig verhulde. Vondel schreef bijvoorbeeld publieke dankgedichten voor enkele mecenassen die hem geschenken of geldbedragen gaven. Hij deed dat op neutrale wijze: hij ging niet in op de waarde van het geschenk of de hoogte van het bedrag en hij presenteerde de steun van mecenassen als iets onnodigs, iets wat hem overkomen was eerder dan dat hij erop uit was. ${ }^{41}$ Verhullender is het feit dat hij de bemiddelaar bij de structurele ondersteuning door de Amsterdamse stadsregering in de laatste twintig jaar van zijn leven (2.b.i), burgemeestersvrouw Anna van Hoorn, enkel impliciet bedankt door in 1659 zijn tragedie Jephta aan haar op te dragen, zonder in het opdrachtgedicht aan haar rol te refereren (1.a.ii). ${ }^{42}$

Deze verschillen tussen Vondel en Kloos wijzen op verschillen in de manier waarop zeventiende- en laat negentiende-eeuwse auteurs omgingen met (particuliere) mecenassen, en de mate waarin symbolisch kapitaal en economisch kapitaal samengingen in de beeldvorming. Welke rol speelden 
de dankgedichten in de relatie tussen Vondel en zijn mecenassen? Wat had Kloos zijn mecenassen te bieden als zij niet publiekelijk konden pronken met het ondersteunen van een vooraanstaand dichter? Welke poëticale context bepaalde dat de toekenning van symbolisch kapitaal in het geval van Vondel wél en in het geval van Kloos niet samen kon gaan met enige verwijzing naar economische verdiensten? Maar ook: waarom was het in beide gevallen toch cruciaal zo min mogelijk aandacht aan die verdiensten te besteden en zich er zelfs tegen af te zetten?

\section{De blikopener: aandachtspunten}

Uit de beschrijving van de posities van Kloos en Vondel in het schema blijkt al dat verschillen in de beschikbaarheid van bronnen maken dat vergelijkingen tussen de periodes niet altijd op alle niveaus kunnen plaatsvinden. Het is lang niet altijd zo dat we voldoende bronnen hebben om iets te kunnen zeggen over de economische verdiensten van een auteur of diens houding ten aanzien daarvan: ook dat moet worden meegenomen in een analyse omdat diachrone vergelijkingen anders snel een vertekend beeld opleveren. In het algemeen geldt dat er minder bronnen zijn als we verder teruggaan in de tijd, met name als het gaat om institutioneel bronmateriaal. Voor oudere periodes hebben we daarom soms alleen de uitingen van de auteurs zelf om ons op te verlaten. De beschikbaarheid van bronnen die informatie bieden over economische verdiensten kan echter voor elke periode een probleem opleveren, al was het maar omdat het onderwerp in het verleden nauwelijks op de kaart heeft gestaan. Hier moeten we ons bij onderzoek dat vertrekt vanuit de blikopener rekenschap van geven.

Er zijn ook andere aandachtspunten bij analyses vanuit de blikopener. Het onderscheid tussen publiek en niet-publiek is soms niet fijnmazig genoeg. Zo is het van belang rekening te houden met de omvang van de publieke en niet-publieke doelgroepen en met het feit dat er binnen de verschillende doelgroepen (of 'publieken') specifieke groepen of individuen aangesproken kunnen worden, aan wie de boodschap over de verdiensten aangepast wordt. Het discours kent dus vaak een grote verfijning.

Het is immers één ding om te onderzoeken wat auteurs precies onthulden en verhulden, hoe ze dat deden en waarom, maar die vragen krijgen pas echt betekenis als je ook onderzoekt tegenover wie ze dat deden. Veel auteurs waren tegenover collega-schrijvers veel openhartiger en eerlijker over hun grote (of juist kleine) winstbelustheid en bijbehorende strategieën dan ze en public of in de media waren. Het omgekeerde (winstbelustheid in 
het openbaar, terughoudendheid tegenover peers) is veel moeilijker voor te stellen, maar iets ervan zien we misschien terug in de eigenzinnige en vaak expliciet pro-kapitalistische publieke beeldvorming van Arnon Grunberg. Zowel economische keuzes als frame-gedrag krijgen meer context als we ook dit onderscheid in ogenschouw nemen.

Een laatste aandachtspunt betreft de stap van observatie naar interpretatie. De exemplarische uitingen die wij ter verduidelijking tussen haakjes in het schema hebben opgenomen, lijken heel eenduidig, maar uitingen zijn dat uiteraard vaak helemaal niet. Er kan sprake zijn van heel impliciete uitingen, zoals het uitnodigen van een potentiële mecenas voor een boekpresentatie (met het oog op eventuele ondersteuning op de lange termijn); er kan sprake zijn van ironiserende uitingen, zoals in de zelfrepresentatie van Reve; en er kan sprake zijn van uitingen waarvan onduidelijk is of ze al dan niet gerelateerd moeten worden aan het schrijverschap, zoals een auteursportret met een dure auto of mantel-impliceert zo'n portret altijd dat een auteur openlijk verdient met zijn of haar auteurschap, of kan dat geld net zo goed ergens anders vandaan komen? En wat zegt het in dat geval dat een auteur zich zo welvarend laat portretteren? Op het situeren van uitingen in het schema moet dus altijd een interpretatieve stap volgen, waarbij (al dan niet door de positionering in het schema gemotiveerde) contextualisering van groot belang is. In dit themanummer zijn de artikelen 'Loon, lust, liefdadigheid' en 'Krijg je nog rente voor een lied?' voorbeelden van zulke contextualiserende interpretaties die vertrokken zijn vanuit de blikopener. In het eerstvolgende artikel, 'Echte schrijvers zijn niet te koop', heeft de blikopener een centralere plaats: in dit stuk situeren we een veelheid aan casussen in het schema met als doel spanningen, constanten en discontinuïteiten in de geschiedenis van auteursverdiensten op het spoor te komen waarnaar in de toekomst nader onderzoek gedaan kan worden.

\section{Noten}

1 Deze tekst is het resultaat van intensieve samenwerking met iedereen die aan (het ontstaan van) dit themanummer heeft bijgedragen: Sander Bax, Johan Oosterman, Jeroen Salman, Rob van der Zalm en Lieke van Deinsen.

2 Recente voorbeelden zijn bijvoorbeeld Jansen \& Laan (2015) en Honings, Marion \& Vergeer (2018).

3 Zie voor deze redenering bijvoorbeeld ook Cummings \& Simpson (2010), 2.

4 De Pourcq (2018), p. 5 .

5 Dubois (2018); Maissen \& Mittler (2018); Le Goff (2015); Berensmeyer, Buelens \& De Moor (2012); Cummings \& Simpson (2010).

6 Berensmeyer, Buelens \& De Moor (2012); Turnovsky (2010); Ascoli (2008). 
7 Geerdink (2012).

8 Bouwmeester, Geerdink \& Ham (2015), 231-233.

9 Bourdieu (1986), 47 en 53-55. Met economisch kapitaal kan niet rechtstreeks symbolisch kapitaal gekocht worden; voor omzetting van de een in de ander is vaak een 'tussenconversie' via cultureel kapitaal noodzakelijk.

10 Bourdieu (1986), 47.

11 Bourdieu (1986), 46.

12 Hoewel Bourdieu economisch kapitaal wel omschrijft als de kapitaalsoort waar alle andere vormen van kapitaal van zijn afgeleid, zie Bourdieu (1986), 252.

13 Bourdieu (1992), 202; zie voor de mogelijkheid sociaal en symbolisch kapitaal te accumuleren 348, en voor de conversie van de ene soort kapitaal in de andere 36 o.

14 Bourdieu (1994), 161-162.

15 Bourdieu (1994), 186.

16 Praat (2014).

17 Bourdieu heeft het herhaaldelijk letterlijk over 'accumulatie' van symbolisch kapitaal: net als economisch, cultureel en sociaal kapitaal kan ook symbolisch kapitaal zich (via de erkenning van anderen) bij een auteur ophopen, zie bijvoorbeeld Bourdieu (1992), 206 en 239 .

18 Abrams (1953).

19 Sötemann (1985), 99-102.

20 Ruiter \& Smulders (2009) gaan op dit onderscheid tussen Abrams (= vooral diachroon) en Sötemann (= vooral synchroon) in.

21 Laan (2010) bespreekt de geschiedenis van (het samenkomen van) de poëtica-analyse en de studie naar het literaire veld in Nederland.

22 Van Rees en Dorleijn (2006), 19.

23 Sleiderink (2015), Mertens (2015) en Beekman (2015). Jansen en Laan hebben het over 'de voorwaarden waaronder literatuur ontstaat', zie Jansen \& Laan (2015), 18.

24 Schenkeveld-van der Dussen (1984), 75-92.

25 Greenblatt (2005).

26 Cheney \& De Armas (2002).

27 Zie over deze concepten en hun invloed op de vroegmoderne neerlandistiek ook Geerdink (2012), 15-19.

28 Dat blijkt heel duidelijk uit het deel van de $G N L$ over de achttiende-eeuwse Republiek, waarin een hoofdstuk gewijd is aan 'De boekenmarkt en letterkundige netwerken', met daarbinnen een paragraaf "Schryvers om den broode", zie Leemans \& Johannes (2013), 79-155.

29 Van Oostrom (1982), 23-25.

30 Sleiderink (2003).

31 Inspiratiebronnen bij het ontwerpen van het schema waren de posturetheorie van Meizoz (Meizoz (2007) en (2010)) voor het onderscheid tussen discursief en niet-discursief en Berensmeyer, Buelens \& Demoor (2009), die ten behoeve van een transhistorische geschiedenis van het auteurschap over auteurschap als 'cultural performance' spreken en nadrukkelijk focussen op een veelheid aan 'uitingen' (bij hen: handelingen) van auteurs.

32 Daarbij willen we opmerken dat een discursieve uiting ook altijd een non-discursieve kant bevat: een uitspraak kun je ook altijd als handeling of interventie beschouwen. Ook non-discursieve uitingen gaan vaak gepaard met uitspraken, dus met discursieve uitingen. De twee categorieën zijn dus theoretisch wel te scheiden, maar in de praktijk lukt dat nauwelijks. 
33 Publieke discursieve uitingen betreffen het literaire werk in zeer brede zin: fictie en nonfictie, maar ook interviews, televisie-optredens etc.

34 Zie ook Praat (2014), 128 en 170.

35 We weten overigens dat Reve in dit soort fotografiesessies in hoge mate 'de leidende partij' was: hij had uitgesproken ideeën over hoe hij in beeld gebracht wilde worden. Met dank aan Edwin Praat, die ons hierop wees.

36 Een boeiende analyse van de uitingen van Reve, inclusief de reacties die hij daarmee opriep, is te vinden in Lijster (2012).

37 Zie over de publicatie Porteman \& Smits-Veldt (2008), 399-400.

38 Van den Braber (2016).

39 Brandt (1682), 61-64.

40 Zie Spies (1991), 210-211, 214.

41 Zie bijvoorbeeld Vondel (1931), vs. 49-54.

42 Zie voor de opdracht Vondel (1935).

\section{Literatuur}

Abrams, M.H., The Mirror and the Lamp. Romantic Theory and the Critical Tradition, Oxford University Press, Oxford, 1953.

Ascoli, Albert Russell, Dante and the Making of a Modern Author, CUP, Cambridge, 2008.

Beekman, Klaus, 'De overheid (negentiende eeuw-heden)', in: Jeroen Jansen \& Nico Laan (red.), Van hof tot overheid: geschiedenis van literaire instituties in Nederland en Vlaanderen, Verloren, Hilversum, 2015, 285-305.

Berensmeyer, Ingo, Gert Buelens \& Marysa Demoor, 'Authorship as Cultural Performance. New Perspectives in Authorship Studies', in: Zeitschrift für Anglistik und Amerikanistik. A Quarterly of Language, Literature and Culture 60, 2012, 1, 5-29.

Bourdieu, Pierre, 'The forms of capital'. John Richardson, Handbook of theory and research for the sociology of education, Greenwood, Westport, 1986.

Bourdieu, Pierre, Les règles de l'art, Seuil, Paris, 1992.

Bourdieu, Pierre, Raisons pratiques. Sur la théorie de l'action, Seuil, Paris, 1994.

Bouwmeester, Gerard, Nina Geerdink, Nina \& Laurens Ham, 'Een veelstemmig verhaal. Auteurschap in de Geschiedenis van de Nederlandse literatuur', in: Nederlandse Letterkunde, 20, 2015, 3, 215-236.

Braber, Helleke van den, 'De nieuwe gids and its informal patronage system', in: Journal of European periodical studies 1, 2016, 1, 53-69. https://doi.org/10.21825/jeps.vi1..2577.

Brandt, Geeraardt, 'Het leven van Joost van den Vondel', in: J.V. Vondels Poëzy of Verscheide Gedichten. Op een nieu by een vergadert, en met veele ook voorheen nooit gedrukte dichten vermeerdert: Mitsgaders een aanleidinge ter Nederduitsche Dichtkunste, en het Leven des Dichters, Leonard Strik, Franeker, 1682.

De Pourcq, Maarten, 'General introduction', in: De Pourq, Maarten \& Sophie Levie (red.), European Literary History. An Introduction, Routledge, Londen/New York, 2018, 1-11.

Cheney, Patrick \& Frederick A. de Armas, European literary careers. The author from antiquity to the Renaissance. University of Toronto Press, Toronto, 2002.

Cummings, Brian \& James Simpson (eds.), Cultural Reformations. Medieval and Renaissance in Literary History, OUP, Oxford, 2010.

Dubois, Sebastién, 'The Price of Rhymes. The Evolution of Poets' Status throughout History', in: Poetics 70, 2018, 39-53. 
Geerdink, Nina, Dichters en verdiensten. De sociale verankering van het dichterschap van Jan Vos (1610-1667), Verloren, Hilversum, 2012.

Goff, Jacques le, Must we divide History into Periods?, Colombia University Press, New York, 2015.

Greenblatt, Stephen, Renaissance self-fashioning. From More to Shakespeare, University of Chicago Press, Chicago, 2005.

Honings, Rick, Olga van Marion \& Tim Vergeer (red.), Van Constantijntje tot Tonio. Het dode kind in de Nederlandse literatuur, Verloren, Hilversum, 2018.

Jansen, Jeroen \& Nico Laan, Van hof tot overheid. Geschiedenis van literaire instituties in Nederland en Vlaanderen, Verloren, Hilversum, 2015.

Laan, Nico, 'De studie van literatuuropvattingen', in: G.J. van Bork \& N. Laan, Van romantiek tot postmodernisme. Opvattingen over Nederlandse literatuur, Coutinho, Bussum, 2010.

Leemans, Inger \& Gert-Jan Johannes, Worm en donder. Geschiedenis van de Nederlandse literatuur. De Republiek. 1700-180o, Prometheus, Amsterdam, 2013.

Lijster, Thijs, 'Geldwolf Reve', De Groene Amsterdammer, 9 november 2012.

Maissen, Thomas \& Barbara Mittler, Why China did not have a Renaissance - and why that matters. An Interdisciplinary Dialogue, Oldenbourg, De Gruyter, 2018.

Mertens, Thom, 'Het middeleeuwse klooster als literaire instelling (dertiende-zestiende eeuw)', in: Jeroen Jansen \& Nico Laan (red.), Van hof tot overheid. Geschiedenis van literaire instituties in Nederland en Vlaanderen, Verloren, Hilversum, 2015, 41-65.

Oostrom, F.P. van, 'Maecenaat en Middelnederlandse letterkunde', in: J.D. Janssens (red.), Hoofsheid en devotie in de middeleeuwse maatschappij. De Nederlanden van de 12e tot de 15e eeuw. Handelingen van het wetenschappelijk colloquium te Brussel 21-24 oktober 1981, Vrienden van de Kapellekerk, Brussel, 1982, 21-40.

Porteman, Karel, \& Mieke B. Smits-Veldt, Een nieuw vaderland voor de muzen. Geschiedenis van de Nederlandse literatuur 1560-1700, Bert Bakker, Amsterdam, 2008.

Praat, Edwin, Verrek, het is geen kunstenaar. Gerard Reve en het schrijverschap. Amsterdam University Press, Amsterdam, 2014.

Rees, Kees van en Gillis J. Dorleijn, De productie van literatuur. Het Nederlandse literaire veld 180o200o, Vantilt, Nijmegen, 2006.

Ruiter, Frans en Wilbert Smulders (red.), Alleen blindgeborenen kunnen de schrijver verwijten dat hij liegt. Over het schrijverschap van Willem Frederik Hermans, Bezige Bij, Amsterdam, 2009.

Schenkeveld-van der Dussen, M.A., 'Poëzie als gebruiksartikel. Gelegenheidsgedichten in de zeventiende eeuw', in: M. Spies (red.), Historische letterkunde. Facetten van vakbeoefening, Wolters-Noordhoff, Groningen, 1984.

Sleiderink, Remco, 'Het hof (ca. 1150-1450)', in: Jeroen Jansen \& Nico Laan (red.), Van hof tot overheid. Geschiedenis van literaire instituties in Nederland en Vlaanderen, Verloren, Hilversum, 2015, 21-40.

Sleiderink, Remco, De stem van de meester. De hertogen van Brabant en hun rol in het literaire leven (1106-143o), Prometheus, Amsterdam, 2003.

Sötemann, A.L., Over poëtica en poëzie. Red. W.J. van den Akker en G.J. Dorleijn. Wolters-Noordhoff, Groningen, 1985 .

Spies, Marijke, 'Betaald werk? Poëzie als ambacht in de 17e eeuw', Kunst in opdracht in de Gouden Eeuw. Speciaal nummer van Holland 23, 1991, 210-224.

Turnovsky, Geoffrey, The Literary Market. Authorship and Modernity in the Old Regime, University of Pennsylvania Press, Philadelphia, 2010.

Vondel, Joost van den, 'Danckoffer aan Jakob, Aertsbisschop van Mechele', in: J.F.M. Sterck e.a. (red.), De werken van Vondel. Deel 5, 1645-1656, De Maatschappij voor goede en goedkoope lectuur, Amsterdam, 1931, 142-143. 
Vondel, Joost van den, Jephta, in: J.F.M. Sterck e.a. (red.), De werken van Vondel. Deel 8, 1656-166o, De Maatschappij voor goede en goedkoope lectuur, Amsterdam, 1935, 771-772.

\section{Over de auteurs}

Helleke van den Braber is hoogleraar Mecenaatstudies aan de Universiteit Utrecht (sinds 2020) en universitair docent Cultuurwetenschap aan de Radboud Universiteit Nijmegen (sinds 2002). Ze promoveerde in 2002 op een onderzoek naar mecenaat in de Nederlandse literatuur tussen 1900 en 1940. Sindsdien doet ze onderzoek naar de theorie en geschiedenis van het geven aan cultuur, naar burgerschap en kunstenaarschap, en naar de productieve en complexe uitwisseling tussen weldoeners en kunstenaars. E-mail:h.m.vandenbraber@uu.nl

Nina Geerdink is universitair docent vroegmoderne Nederlandse letterkunde aan de Universiteit Utrecht. In het kader van haar NWO-Veni-project (2016-2020) onderzoekt zij de verdienmogelijkheden van auteurs in de vroegmoderne tijd in relatie tot het discours daarover.

E-mail: n.geerdink@uu.nl

Laurens Ham is universitair docent moderne Nederlandse letterkunde aan de Universiteit Utrecht. Hij werkt momenteel aan een NWO-Veni-project (2018-2022) over de rol van Nederlandse auteurs in het literatuurbeleid en aan een publieksstudie over Nederlandstalige protestliedjes.

E-mail:1.j.ham@uu.nl

Remco Sleiderink is hoogleraar Middelnederlandse letterkunde aan de Universiteit Antwerpen. De handschriftelijke overlevering en het ontstaan van literatuur in de dynamiek tussen hof en stad hebben zijn bijzondere belangstelling. E-mail: remco.sleiderink@uantwerpen.be 